\title{
Review. Teaching of National Languages in V4 Countries, edited by Marek Pieniążek and Stanislav Stěpáník, 2016
}

\author{
Praha, Faculty of Education of Charles University, 177 pp., \\ http://hdl.handle.net/11716/1265 ISBN: 978-80-7290-926-1
}

Ivana Hurytová

Charles University

The teaching of national languages involves not only the subject matter itself in all its breadth and complexity, but also its specific field of didactics. Serving as a tool of communication, the national language often plays a central role among other school subjects. Additionally, it reflects the history of the nation and its political situation and contributes significantly to national self-awareness and identity.

The reviewed monograph is the result of a year-long project of the same name, funded by the Visegrad Fund. The project was based on the common research of four universities from the Czech Republic, Hungary, Poland, and Slovakia on the issue of the teaching of national languages in each country. These states were chosen as they have many similar features, due to specific Central European geopolitical conditions, history, and development of education. All of them are quite young states as they (re)emerged after World War I (The Czech Republic and Slovakia formed one state until 1993), which has led to the independence of their national languages and their primary status at school. All these countries were hit very hard by World War II, after which communist regimes were established. It was not until 1989 that the regime fell, and the countries were opened to new influences of Western education and culture. These historical disturbances have, naturally, had an impact on their national languages and their teaching.

The members of the research team, which included the authors of the publication under review, were established scholars, linguists and literature educators: 
Marek Pieniążek from the Pedagogical University of Cracow (Poland), János Imre Heltai, Tibor M. Pintér and Réka Sólom from the Faculty of Humanities of Károli Gáspár University of the Reformed Church in Budapest (Hungary), Stanislav Štěpánik and Martina Šmejkalová from the Faculty of Education of Charles University in Prague (Czech Republic) and Silvia Pokrivčáková and Anton Pokrivčák from the Faculty of Education of Constantine the Philosopher University in Nitra (Slovakia). The general aim of the above mentioned project was to create a platform that would give the opportunity to see the profiles of the national educational systems and their specific contemporary conditions in countries that share common history and face very similar issues, giving a special attention to the role of national languages in the process of creating and maintaining cultural identity of the young generation in Central Europe. Document, textbook, curricula and historical analyses, classroom observation, interviews, and the analysis of resources and specialized literature on this topic in each country were used to collect the data. Over one year they also organized a series of workshops, during which the researchers' experiences and interim results were exchanged and discussed.

The main aim of the book was to summarize the outcomes of the project and compare the systems of teaching national languages in the four countries of the Visegrad group. The monograph contains four thorough chapters on teaching national languages in each country involved. All the chapters have the same structure reflecting the research, which makes the book very clear and gives the reader a good orientation. The issues covered include: school policy; historical milestones influencing the school system and national language education; current state of teaching national language (curriculum, textbooks, practice in schools, standardised tests and examinations); teacher training and the teaching of national language as a second or a foreign language.

As the researchers initially hypothesised, the research revealed many similarities, in both theoretical and pragmatic approaches, based on the specific Central European geopolitical situation and the historical development. All four teams referred to the communicative dimension of language teaching, wished to combine literary and language teaching and promoted supporting the development of language competence through the mediatization of language experience. However, despite similar attitudes to language teaching and mediating it through values, there were also some dissimilarities as to the position of the national language in each country resulting from different education policies, methods of school management and legal regulations. The monograph gives a clear overview of the possibility of 
exploring the systems of teaching national languages without hiding the problems and shortcomings of these systems.

The only thing which could be seen critically is the imbalance in the content of some of the corresponding chapters. For example, in chapter 2 the description of the Polish history is briefer than those of the other countries and concentrates mainly on the situation after the fall of the communist regime in 1989. Some differences can also be observed in chapter 5: whereas some contributions offer an indepth insight into the situation of teaching their national language as a second and a foreign language, others put more emphasis only on one of these aspects. This issue is rather complicated and can hardly be reduced to several pages. The different approaches also partly reflect the divergences in the historical development and present situation of the participating states, as well as the status of certain national languages.

The book is unique as it is the first collective monograph which offers the opportunity to compare the systems of teaching national languages and literature in the Visegrad countries. Despite the similarities of the regions and histories of all the states involved, there are some differences in the current state of teaching. One particular example, which could be inspiring to follow, is the Criterion Exam on Mother Tongue in Hungary that consists of four parts: communication, rhetoric, orthography and linguistic normativity, and is compulsory for every student who wants to become a teacher (irrespective of the subject taught). The Hungarian Core curriculum also considers students' ability to recognise the differences between one's mother tongue and foreign languages as a learning objective. Another good example is the Polish language textbook series I like it! The concept of these textbooks consists in the anthropocentric approach and an integral connection of language education with literature. Their authors resigned from the chronological and schematic course of education and from teaching ready notions.

The book under review also presents the paths which did not lead to the expected results or were even harmful for education. Almost all involved countries reported both historical and current problems regarding the excessive number of exams at various grades of school education. This situation often forces teacher to prepare the students for the exams rather than engage in distinctive, authentic, and creative teaching. On the other hand, sometimes the tests reveal serious shortcomings in language teaching. For example, in Slovakia testing in $5^{\text {th }}$ and $9^{\text {th }}$ grade confirmed that children have significantly better performance in facts-based tasks than in conceptual knowledge, and better results in the tasks testing learners' memory 
than in the application tasks. Understanding such examples and results can help others to avoid various inappropriate solutions.

The Polish contribution warns against the increasing status of English and the consequent shift of attention from developing Polish language competences to the language of the global community. The claim that the Polish language becomes less important than English is quite strong and should be analysed also in the context of other neighbouring countries influenced by English. In view of the situation before 1989, it was somehow natural and to a certain extent even desirable that globalization, the influence of foreign culture and free movement within the borders of the European Union should bring new opportunities, expand the horizons of science and art, and enrich the languages of all the involved states.

What is more alarming and common to all the V4 countries is the gap between the didactic theory and school practice. There are theoretical works, which, starting from the seventies, have advocated the communicative conception of language teaching, but school practice becomes fixed in rigid positions of the grammatical and historicizing approaches, isolating the language and its system from live and natural communication. In such a situation, it is understandable that the popularity of lessons of national languages is lower than of other subjects.

Therefore, the idea of revision of the conception of teaching national language in these countries is highly topical, and there is un urge for general, researchinformed reforms. In this respect the Slovak primary school is probably most advanced due to the psycho- and onthodidactic research done at the Faculty of Education at the University of Prešov.

For these reasons it is extremely important to discuss such issues on the international level to share examples of good practice as regards the basic teacher qualification (at the moment it is a university Master's degree in all involved countries, and has been unchanged in spite of political waves) and other problems mentioned above. It may also help to avoid infertile experiments, insufficiently thoughtout changes, and over-testing, in which schools had to devote a lot of time to examination preparation rather than to real teaching.

The research described in this monograph has indicated several problems and raised some questions, which opens the perspectives of other more specialized and in-depth exploration of comparative approaches in education. 


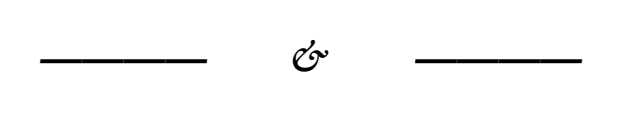

\section{IVANA HURYTOVÁ}

Ivana Hurytova graduated from the Faculty of Arts at Charles University, now she has done a doctorate at the Faculty of Education. She has rich experience in education, from direct teaching of Czech language at various degrees as well as from administrating educational projects in a foundation supporting higher education.

ivana.hurytova@pedf.cuni.cz http://orcid.org/0000-0002-0543-5615

Hurytová, I. (2020). Review. Teaching of National Languages in V4 Countries, edited by Marek Pieniążek and Stanislav Štěpáník, 2016. Bellaterra Journal of Teaching \& Learning Language \& Literature, 13(2), e860. https://doi.org/10.5565/rev/jtl3.860 